\title{
Silicon as resistance inducer in to control black aphid Aphis craccivora Koch, 1854 in Phaseolus lunatus lima beans
}

\author{
Silício como indutor de resistência no controle do pulgão preto Aphis \\ craccivora Koch, 1854 em fava Phaseolus lunatus
}

\author{
Gilson Lages Fortes Portela1* (D), Paulo Roberto Ramalho Silva² (D), José Edmir Girão Filho² (D), \\ Luiz Evaldo de Moura Pádua ${ }^{2}$ (D), Luiz Carlos de Melo Júnior ${ }^{1}$ (D)
}

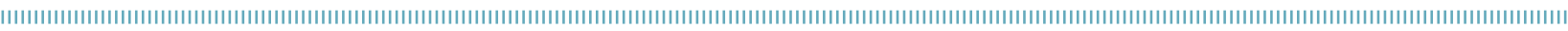

\begin{abstract}
In Brazil, there are few records of insects associated with the cultivation of lima beans; among them, there is the black aphid Aphis craccivora Koch, 1854. The objective of this study was to evaluate the effects of silicon application on the resistance induction of lima bean plants, Phaseolus lunatus, to the black aphid A. craccivora. The experiment was conducted in the Entomology Laboratory of the Phytosanitary Sector of Centro de Ciências Agrárias, Universidade Federal do Piauí (UFPI), Brazil. The effects of the following treatments on biological aspects of the insect were evaluated: silicon applied to soil; silicon applied to soil + leaf; silicon applied to leaf; and control, without silicon application. The following biological variables were evaluated: generation period, reproductive period, and the fertility and daily average of produced nymphs per female. Plant silicon and lignin content were also evaluated. A $1 \%$ solution of silicic acid $(2.0 \mathrm{~g}$ of product diluted in $200 \mathrm{~mL}$ of water) was applied around the plant stem (on soil), 15 days after emergence. Leaf application was performed with a 1-L spray, 5 days after the soil application. The non-preference of $A$. craccivora on lima beans was also evaluated. The evaluations were performed after 48 and 72 hours of infestation by counting nymphs and adults at each leaf section. Silicon application reduces nymph production, thereby interfering in the biological aspects of $A$. craccivora. Therefore, it can be used in cowpea pest management programs.
\end{abstract}

KEYWORDS: antibiosis; behavior; integrated pest management; induced resistance.
RESUMO: São poucos os registros no Brasil de insetos associados à cultura da fava; entre eles, destaca-se o pulgáo preto Aphis craccivora Koch, 1854. O objetivo deste estudo foi avaliar os efeitos da aplicação de silício na indução de resistência de plantas de feijão-fava Phaseolus lunatus a esse inseto. O experimento foi conduzido no Laboratório de Entomologia do setor de Fitossanidade do Centro de Ciências Agrárias da Universidade Federal do Piauí (UFPI). Os efeitos da aplicação do silício sobre os aspectos biológicos do inseto foram avaliados utilizando os tratamentos: silício aplicado no solo, silício aplicado no solo + folha, silício aplicado à folha; e controle, sem aplicação de silício. Foram avaliadas as variáveis biológicas: duração do período pré-reprodutivo, período reprodutivo e fertilidade, e média diárias de ninfas produzidas por fêmea. Os teores de silício e de lignina nas plantas também foram avaliados. O ácido silícico foi aplicado em uma soluçáo a $1 \%$ ao redor do caule das plantas (no solo), 15 dias após a emergência, diluindo-se $2,0 \mathrm{~g}$ do produto em $200 \mathrm{~mL}$ de água. Já a aplicação foliar foi realizada com um pulverizador de $1 \mathrm{~L}, 5$ dias após a aplicação em solo. A não preferência de $A$. craccivora em feijão também foi avaliada. As avaliaçóes foram realizadas após 48 e 72 horas da infestaçáo, por meio da contagem de ninfas e adultos em cada secção foliar. A aplicação de silício promove a redução da produção de ninfas, interferindo nos aspectos biológicos de $A$. craccivora, podendo ser utilizado em programas de manejo de pragas do feijão-fava.

PALAVRA CHAVE: antibiose; comportamento; manejo integrado de pragas; resistência induzida. 


\section{INTRODUCTION}

Phaseolus lunatus is commonly known as sieve bean, butter bean, double bean, or lima bean, being the latter its most common name. According to OLIVEIRA et al. (2010), lima bean was originated in the American continent and has spread worldwide; it is used as an alternative to the consumption of the traditional Phaseolus vulgaris and Vigna unguiculata beans. VIEIRA (1992) stated that the lima bean plant entered Brazil with slave trade, and it is currently cultivated in all Brazilian states, especially by rural populations of Northeastern Brazil.

VIEIRA (1992) reported that there are few studies on insects associated with lima beans. The black aphid, Aphis craccivora Koch, stands out because it has a lot of potential to damage crops. According to SANTOS; QUINDERÉ (1988), the first 35 days after the emergence of the insect is the period of greatest concern. These insects are generally located on terminal shoots and can also attack pods. The great concern with aphids is that they are vectors of viruses, transmitting the viruses already during probing.

Damage is caused by $A$. craccivora nymphs and adults (DE LA PAVA; SEPÚLVEDA-CANO, 2015). They are small insects, of approximately $1.5 \mathrm{~mm}$ long, that range from light yellow to dark green, and live in colonies under leaves, young shoots, and flowers (SILVA et al., 2005). Another problem mentioned by the authors is that this aphid causes the appearance of sooty mold, which damages the plant's photosynthesis and respiration mechanisms.

TAIZ; ZEIGER (2013) stated that defensive mechanisms allow plants to respond to injuries caused by insects and identified the substances present in the insects' saliva that induce defense responses. These substances saliva are called elicitors and are responsible for triggering the onset of plant defense responses.

When attacked by pathogens and insects, plants emit a signal that initiates the induced defense. This signal depends on endogenous regulators, such as salicylic acid, ethylene, and jasmonic acid (ERB et al., 2012). According to REZENDE et al. (2007), the signal is emitted when molecules of the inducer bind to receptor molecules of the plant cell.

Induced resistance consists of increasing the resistance of plants to insect attacks, using products called inducers and without changing the genetic composition of the plant. This method is easy to use and has a relatively low cost; therefore, it is an alternative to conventional control (ALMEIDA et al., 2008).

Silicon stands out among inducers. Silicon deposition induces plant resistance against some insects through the formation of physical, chemical, and structural barriers. The increase in thickness (i.e., physical barrier) hampers the penetration of insects, reducing their survival rate and leading to a decrease in plant susceptibility (KORNDÖRFER et al., 2011). Silicon is the most abundant element on the Earth's crust (REYNOLDS et al., 2009).
Considering such scenario, this study aimed at evaluating the effect of silicon as an inducer of resistance of $P$. lunatus (lima bean) against the attack of $A$. craccivora.

\section{MATERIALS AND METHODS}

The experiment was conducted from July to December 2016 at Centro de Ciências Agrárias of Universidade Federal do Piauí, located in Teresina City, Piauí State, Brazil (geographical coordinates $05^{\circ} 05^{\prime} 21^{\prime \prime} \mathrm{S}$ and $42^{\circ} 48^{\prime} 07^{\prime \prime}$ W; elevation $72 \mathrm{~m}$ a.s.l.). Maximum and minimum average temperatures are 34 and $22^{\circ} \mathrm{C}$, respectively, maximum average humidity is $84 \%$, and minimum average humidity is $56 \%$ (PREFEITURA DE TERESINA, 2015).

Lima bean seeds from the accession UFPI 886 (Tianguá), supplied by the lima bean Germplasm Active Bank of Universidade Federal do Piauí (BAGF/UFPI), were planted in 2.8-L jars containing soil, tanned manure, and sand substrates in a 3:1:1 ratio. Five lima bean seeds were planted and, ten days after their emergence, thinning was performed leaving one plant per pot. The plants were cultivated in a greenhouse and irrigated whenever needed.

The aphids were reared on cowpea plants in an acclimatized room at $25 \pm 2^{\circ} \mathrm{C}$ in the phytosanitary laboratory of the Centro de Ciências Agrárias of UFPI. The insects were previously reared in laboratory.

Four treatments with silicon application were tested: silicon applied to soil; silicon applied to soil + leaf; silicon applied to leaf; and the control, without application of silicon. Silicon acid was applied around the plants' stems (onto the soil) 15 days after emergence. The silicon acid was prepared by diluting $2.0 \mathrm{~g}$ of the product in $200 \mathrm{~mL}$ of water. The silicon was applied on the leaves with a 1-L sprayer, five days after soil application.

A free-choice test was performed 24 hours after applying all treatments. Using scissors, of $2 \times 2 \mathrm{~cm}$, leaf sections were cut from plants of each of the four treatments. These leaf sections were placed in 15-cm diameter Petri dishes with a sponge and water in the bottom. Each plate contained a leaf section of each of the four treatments, which were arranged and fixed in a circle, forming an arena. Twenty-five apterous adult aphids were placed in the center of each plate. The plates were kept in a "Bio-Oxygen Demand" (BOD) climate-controlled chamber at $25 \pm 2^{\circ} \mathrm{C}$, relative humidity of $70 \%$, and photophase of 12 hours. Evaluations were performed 48 and 72 hours after placing the aphids by counting the number of adults and live nymphs present in each leaf section.

In the no-choice test, each plate, under the same conditions of the previous test, contained a leaf section from each treatment. One adult was placed on each plate, and 24 hours after placement, they were removed. One nymph was selected 
from the nymphs produced and kept on the plate until its death. The biological variables observed were: duration of the pre-reproductive period, longevity, total fertility, and mean daily fertility of nymphs per female. The levels of lignin and silicon in each treatment were determined.

The experimental design used was entirely randomized, with 10 repetitions for the free-choice test and 30 repetitions for the no-choice test. The data were submitted to analysis of variance and the means were compared using the Tukey test in the BIOESTAT 5.0 software, from 2007 (AYRES et al., 2007).

Silicon content was determined in the soil laboratory at the Soil Department of the Centro de Ciências Agrárias of Universidade Federal de Viçosa, Minas Gerais state, Brazil. Nitric acid and perchloric acid (at a 3/1 ratio) were used for sample extraction. Then, the silicon content was determined using a spectrophotometer.

Lignin content was determined in the Laboratory of Animal Nutrition (Laboratório de Nutrição Animal, LANA) at the Zootechnics Department of the Centro de Ciências Agrárias of Universidade Federal do Piauí. Lignin content was determined using acid detergent fiber (ADF) and the $72 \%$ sulfuric acid method following SILVA (1981).

\section{RESULTS AND DISCUSSION}

No significant differences were found between the treatments in the free-choice test with adults and nymphs 48 and 72 hours after placing $A$. craccivora aphids (Table 1 ). One of the questions raised when using inducers was the time needed for them to start acting; in the case of silicon, a minimum time is needed for the benefits to begin to appear. However, this minimum time has not yet been determined. CRUZ et al.
(1998) stated that the ideal time to perform non-preference evaluations of the greenbug Schizaphis graminum in sorghum is 72 hours or more. COSTA; MORAES (2006) found results like ours when investigating the effect of silicon on Schizaphis graminum in wheat plants, and they found no significant difference between different silicon treatments. In contrast, ALMEIDA et al. (2015) investigated other aphid species in sorghum and corn, and found a significant difference between silicon treatments.

Among the biological parameters herein evaluated, nymph period duration and longevity (Table 2) were the only parameters that were not influenced by any silicon fertilization treatment. Despite the unfavorable situation for the development of the insect, its nymph period and longevity did not change and showed no statistical difference $(\mathrm{p}<0.05)$, compared to the control treatment. These results are similar to those found by COSTA; MORAES (2006) for the aphid Schizaphis graminum in wheat plants, RANGER et al. (2009) for Myzus persicae in Zinnia elegans, and SANTOS et al. (2012) for Tuta absoluta; these studies found no statistical difference among silicon treatments.

A significant difference was found among treatments regarding fertility $(\mathrm{p}<0.05)$ (Table 2$)$. In the treatments silicon was applied to soil and leaf, the best results were seen. In those that the entire dose of silicon was applied to soil and leaf, the reproductive capacity of aphids was affected, because the control without silicon had a much higher production of nymphs compared to these treatments. Silicon application to soil provided lower fertility and several nymphs were compared to the control treatment. The control treatment had a higher daily production of nymphs than the treatment in which silicon was applied to soil and leaf (Table 2). Silicon possibly induces the plant to produce a secondary compound, that is responsible for plant defense, and acts in the plant structure, or in the biochemical part of lima bean plants, leading

Table 1. Number of Aphis craccivora adults and nymphs in the free-choice test on Phaseolus lunatus (lima bean) after applying silicon.

\begin{tabular}{lccccc} 
Treatments & \multicolumn{2}{c}{ Adults } & \multicolumn{3}{c}{ Nymphs } \\
\cline { 2 - 6 } & $\mathbf{4 8} \mathbf{h}^{\text {ns }}$ & $\mathbf{7 2} \mathbf{h}^{\text {ns }}$ & $\mathbf{4 8} \mathbf{h}^{\text {ns }}$ & $\mathbf{7 2} \mathbf{h}^{\text {ns }}$ \\
Silicon applied to soil & $2.80 \pm 0.35$ & $2.20 \pm 0.41$ & $6.50 \pm 1.0$ & $5.40 \pm 0.81$ \\
\hline Silicon applied to soil + leaf & $2.20 \pm 0.48$ & $2.70 \pm 0.53$ & $6.80 \pm 1.38$ & $7.10 \pm 1.34$ \\
\hline Silicon applied to leaf & $2.80 \pm 0.59$ & $1.70 \pm 0.63$ & $7.10 \pm 1.16$ & $4.0 \pm 1.11$ \\
\hline Control & $2.00 \pm 0.36$ & $2.10 \pm 0.48$ & $6.60 \pm 9.90$ & $5.20 \pm 1.33$ \\
\hline
\end{tabular}

${ }^{\mathrm{n}}$ not significant in the $\mathrm{F}$ test, at $5 \%$ significance level.

Table 2. Biological aspects (nymph period, longevity, fertility, and mean number of nymphs per day) of Aphis craccivora in Phaseolus lunatus (lima bean) plants treated with silicon (mean \pm standard error).

\begin{tabular}{lcccc} 
Treatment & Nymph period $^{\text {ns }}$ & Longevity $^{\text {ns }}$ & Fertility & FDM/female \\
\hline Silicon applied to soil & $4.16 \pm 0.11$ & $15.84 \pm 0.65$ & $48.48 \pm 2.18 \mathrm{~b}$ & $4.23 \pm 0.20 \mathrm{a}$ \\
\hline Silicon applied to soil + leaf & $4.16 \pm 0.14$ & $17.20 \pm 0.77$ & $61.81 \pm 1.65 \mathrm{a}$ & $4.74 \pm 0.21 \mathrm{bc}$ \\
\hline Silicon applied to leaf & $4.44 \pm 0.16$ & $16 \pm 0.72$ & $51.44 \pm 2.26 \mathrm{~b}$ & $4.48 \pm 0.23 \mathrm{ab}$ \\
\hline Control & $4.24 \pm 0.13$ & $16.36 \pm 0.65$ & $61.80 \pm 3.14 \mathrm{a}$ & $5.16 \pm 0.22 \mathrm{c}$ \\
\hline
\end{tabular}

${ }^{n s}$ not significant in the F/FDM/female - female daily mean per day tests, at a $5 \%$ significance level. Means followed by the same lowercase letter do not differ statistically from each other in the Tukey test $(p<0.5)$. 


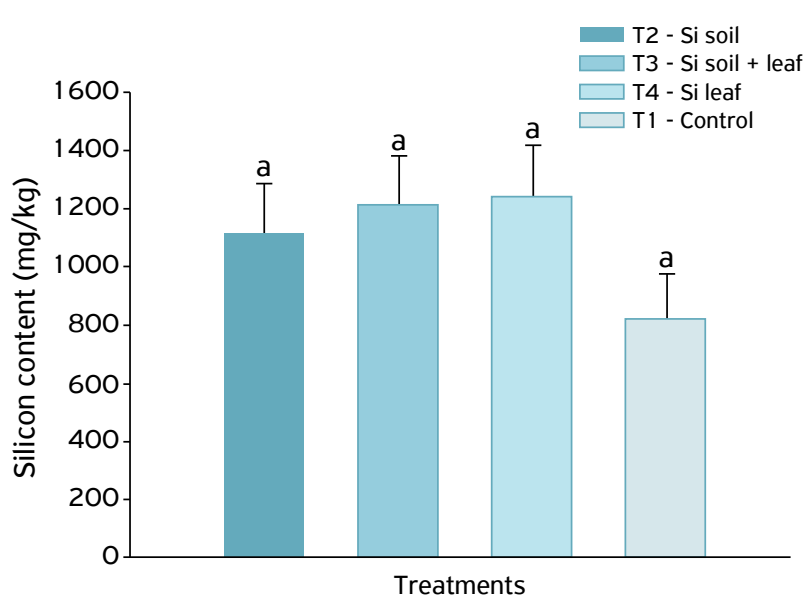

Figure 1. Silicon content $(\mathrm{mg} / \mathrm{kg}$ ) ( \pm standard error) in shoot (leaves and stems) dry mass of Phaseolus lunatus (lima bean) after applying different doses of silicon.

to the production of substances, such as enzymes and phytoalexins. Silicon alters the reproduction of aphids, even in plants that do not normally accumulate silicon. The presence of silicon in plants changes their nutritional quality, hindering the digestibility of food, which leads to the induction of resistance. The insects used in the present study certainly had feeding difficulties, which compromised their reproduction.

Silicon acts in various ways to reduce insect damage. According to REYNOLDS et al. (2009), its various mechanisms of action include lowering digestibility, increasing tissue hardness, producing defensive enzymes, and reducing the inset's reproduction. Silicon possibly increases the presence of substances that reduce aphid reproduction. GOMES et al. (2009), when investigating silicon-fertilized sweet potatoes, found that silicon applied to soil or leaf reduces the fertility of Myzus persicae aphids. PEREIRA et al. (2010), when investigating the greenbug Schizaphis graminum, also found that silicon fertilization reduced the fertility of greenbugs, thus corroborating the findings of the present study.

Silicon content in the leaves and stems of lima beans after the experiment is shown in Figure 1. The control treatment had a lower silicon content than the other treatments, implying a higher fertility; this indicates that silicon may be responsible for the increase in tissue hardness or the production of some substance that hinders insect feeding. According to EPSTEIN (1999), silicon accumulates in the cell wall in the form of amorphous silica, leading to a greater accumulation of lignin, phenolic compounds, peroxidases, and chitinase, which are substances that protect the plant against pathogens and herbivorous insects. According to REYNOLDS et al. (2009), silicon leads to reduced digestibility and, consequently, to lower fertility. Moreover, it also leads to the release of volatiles responsible for attracting natural enemies by improving insect control.

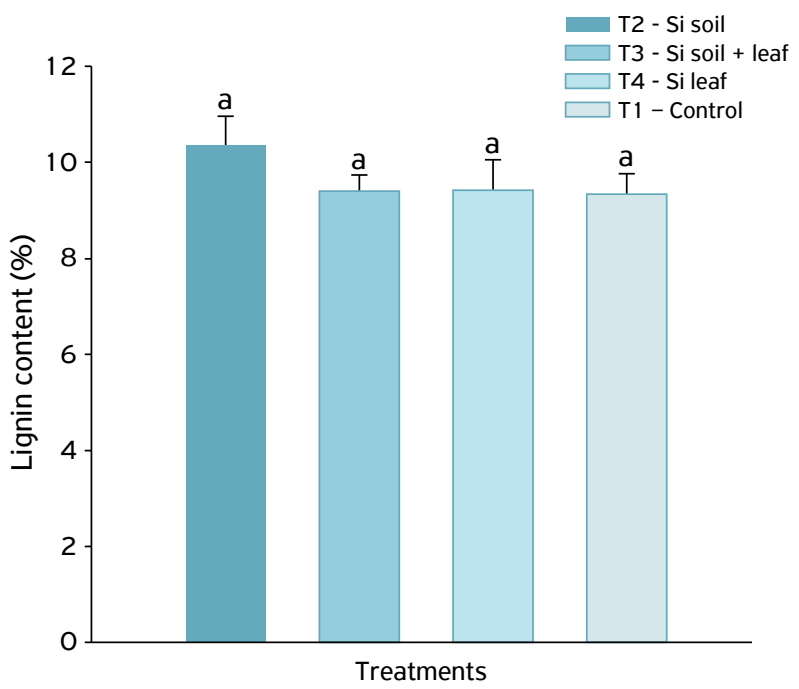

Figure 2. Lignin content (\%) ( \pm standard error) in shoot (leaves and stems) dry mass of Phaseolus lunatus in different treatments.

Several studies present results similar to ours, including those by KEEPING et al. (2009) for Eldana saccharina in sugarcane; KORNDÖRFER et al. (2011) for Mahanarva fimbriolata in sugarcane; COSTA; MORAES (2006) for the aphid Schizaphis graminum in wheat; and NASCIMENTO et al. (2014), who found that the application of silicon in rice affects food preference and the survival of Spodoptera frugiperda caterpillars.

Even though the treatment with the application of silicon to soil tended to have a higher lignin content than the other treatments, there were no statistical differences among them $(\mathrm{p}$ $<0.05$ ). Lignin content is one of several parameters related to resistance induction, but not the only one. According to FREI (2013), cell wall is the first line of defense for plants against pathogens, nematodes, and insects. Lignin is an aromatic polymer, deposited in the cell wall, used for plant defense, among other functions. The lignin content of crops depends on several factors, such as growth phase, genotype, morphological fraction, and environmental conditions (Fig. 2).

Considering that the treatment with silicon did not affect the non-preference experiment, the resistance mechanism is considered an antibiosis. Nonetheless, further research on the use of silicon as an inducer of pest resistance is needed to determine doses, forms of application, number of doses, best time for application, and other factors.

\section{CONCLUSION}

Silicon affects the fertility and number of nymphs of the aphid A. craccivora in P. lunatus (lima bean) cultivation and can be used in insect management programs. 


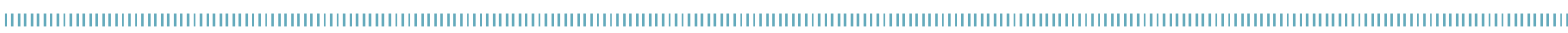
REFERENCES

ALMEIDA, G.D.; PRATISSOL, D.; HOLTZ, A.M.; VICENTINI, V.B. Fertilizante organomineral como indutor de resistência contra a colonização da mosca branca no feijoeiro. Idesia, Chile, v.26, n. 1, p.29-32, 2008. http://dx.doi.org/10.4067/S0718-34292008000100004

ALMEIDA, A.C.S.; SILVA, L.P.; JESUS, F.G.; NOGUEIRA, L.; SOUSA NETO, M.; CUNHA, P.C.R. Efeito de indutores de resistência em híbridos de milho na atratividade do pulgão Rhopalosiphum maidis (Fitch, 1856) (Hemiptera: Aphididae). Revista Agrarian, Dourados, v.8, n.27, p.23-29, 2015.

AYRES, M.; AYRES JUNIOR, M.; AYRES, D.L.; SANTOS, A.S. Bioestat. Aplicações estatísticas nas áreas das ciências biomédicas. Bélem: UFP, 2007.

COSTA, R.R.; MORAES, J.C. Efeitos do ácido silícico e do acibenzolarS-methyl sobre Schizaphis graminum (Rond.) (Homoptera: Aphididae) em plantas de trigo. Neotropical Entomology, v.35, n.6, p.834-839, 2006. http://dx.doi.org/10.1590/S1519-566X2006000600018

CRUZ, I.; VENDRAMIM, J.D.; OLIVEIRA, A.C. Determinação do período de avaliação de não-preferência de sorgo ao pulgão-verde, Schizaphis graminum (Rond.) (Homoptera: Aphididae). Anais da Sociedade Entomológica Brasileira, v.27, n.2, p.299-302, 1998. http://dx.doi.org/10.1590/S0301-80591998000200018

DE LA PAVA, N.; SEPÚLVEDA-CANO, P.A. Biología del áfido negro (Aphis craccivora: Aphididae) sobre fríjol caupi (Vigna unguiculata, Fabaceae). Acta Biológica Colombiana, v.20, n.3, p.93-97, 2015. https://doi.org/10.15446/abc.v20n3.43064

EPSTEIN, E. Silicon. Annual Review of Plant Physiology and Plant Molecular Biology, v.50, p.641-664, 1999. https://doi. org/10.1146/annurev.arplant.50.1.641

ERB, M.; MELDAU, S.; HOWE, G.A. Role of phytohormones in insectspecific plant reactions. Trends in Plant Sciense, v.17, n.5, p.250259, 2012. https://doi.org/10.1016/j.tplants.2012.01.003

FREI, M. Lignin: characterization of a multifaceted crop component. The Scientific World Journal, v.2013, p.1-25, 2013. http://dx.doi. org/10.1155/2013/436517

KORNDÖRFER, A.P.; GRISOTO, E.; VENDRAMIM, J.D. Induction of insect plant resistance to the spittlebug Mahanarva fimbriolata Stål (Hemiptera: Cercopidae) in sugarcane by silicon application. Neotropical Entomology, v.40, n.3, p.387-392, 2011 . http:// dx.doi.org/10.1590/S1519-566X2011000300013

GOMES, F.B.; MORAES, J.C.; NERI, D.K.P. Adubação com silício como fator de resistência a insetos-praga e promotor de produtividade em cultura de batata inglesa em sistema orgânico. Ciência Agrotécnica, Lavras, v.33, n.1, p.18-23, 2009. http://dx.doi. org/10.1590/S1413-70542009000100002

KEEPING, M.G.; KVEDARAS, O.L.; BRUTON, A.G. Epidermal silicon in sugarcane: Cultivar differences and role in resistance to sugarcane borer Eldana saccharina. Environmental and Experimental Botany, v.66, n.1, p.54-60, 2009. https://doi.org/10.1016/j. envexpbot.2008.12.012
NASCIMENTO, A.M.; ASSIS, F.A; MORAES, J.C.; SAKOMURA, R. Não preferência a Spodoptera frugiperda (Lepidoptera: Noctuidae) induzida em arroz pela aplicação de silício. Revista Brasileira Ciências Agrárias, Recife, v.9, n.2, p.215-218, 2014. https:// doi.org/10.5039/agraria.v9i2a3930

OLIVEIRA, M.D.C.P.; MEIRELLES, A.C.S.; LOPES, A.C.A.; GOMES, R.L.F. Fenologia e desenvolvimento vegetativo do feijao-fava. In: LOPES, A.C.D.A.; GOMES, R.L.F.; ARAUJO, A.S.F.D. A cultura do feijão-fava no meio-norte do Brasil. 1. ed. Teresina: EDUFPI, 2010. p.272.

PEREIRA, R.R.C.; MORAES, J.C.; PRADO, E.; DA COSTA, R.R. Resistance inducing agents on the biology and probing behaviour of the greenbug in wheat. Scientia Agricola, v.67, n.4, p.430-434, 2010. http:// dx.doi.org/10.1590/S0103-90162010000400009

PREFEITURA DE TERESINA. Teresina: caracterização do município, 2015. Available from: http://semplan.teresina.pi.gov.br/ wp-content/uploads/2015/02/TERESINA-Caracteriza\%C3\% 83\%C2\%A7\%C3\%83\%C2\%A3o-do-Munic\%C3\%83-pio-2015. pdf. Access on: Jan. 252018.

RANGER, C.M.; SINGH, A.P.; FRANTTZ, J.M.; LOCKE, J.C.; REDING, M.E.; VORSA, N. Influence of silicone on resistance of Zinnia elegans to Myzus persicae (Hemiptera: Aphididae). Environmental Entomology, Lanham, v.38, n.1, p.129-136, 2009. http://dx.doi. org/10.1603/022.038.0116

REYNOLDS, O.L.; KEEPING, M.G.; MEYER, J. H. Silicon-augmented resistance of plants to herbivorous insects: a review. Annals of Applied Biology, v.155, n.2, p.171-186, 2009. https://doi. org/10.1111/j.1744-7348.2009.00348.x

REZENDE, M.L.V.; COSTA, J.B.; CAVALCANTTI, F.R.; RIBEIRO JUNIOR, P.M.; CAMILO, F.R. Seleção de extratos vegetais para indução de resistência e ativação de respostas de defesa em cacaueiro contra a vassoura-de-bruxa. Fitopatologia Brasileira, v.32, n.3, p.213-221, 2007.http://dx.doi.org/10.1590/SO100-41582007000300005

SANTOS, J.H.R.; QUINDERÉ, M.A.W. Distribuição, importância e manejo das pragas do caupi no Brasil. In: ARAÚJO, J.P.P.; WATT, E.E. (Org.). O caupi no Brasil. Brasília: IITA/EMBRAPA, 1988. p.605-658.

SANTOS, M.C.; JUNQUEIRA, A.M.N.; SÁ, V.G.M.de; ZANUNCIO, J.C.; BAUCH, M.A.; SERRÃO, J.E. Efeito do silício em aspectos comportamentais e na história de vida de Tuta absoluta (Meyrick) (Lepidoptera: Gelechiidae). Revista Brasileira de Agropecuária Sustentável, v.2, n. 1, p.76-88, 2012. https://doi.org/10.21206/rbas.v2i1.61

SILVA, D.J. Análise de alimentos (métodos químicos e biológicos). Viçosa: UFV, 1981. 166p.

SILVA, P.H.S.; CARNEIRO, J.S.; QUINDERÁ, M.A.W. Pragas. In: FREIRE FILHO, F.R.; LIMA, J.A.A.; RIBEIRO, V.Q. (Ed.). Feijão caupi: avanços tecnológicos. Brasília: Embrapa Informação Tecnológica, 2005. p.29-92.

TAIZ, L.; ZEIGER, E. Fisiologia vegetal. 5.ed. Porto Alegre: Artmed, 2013. 848p.

VIEIRA, R.F. A cultura do feijão-fava. Informe Agropecuário, Belo Horizonte, v.16, n.174, p.30-37, 1992.

This is an open access article distributed under the terms of the Creative Commons license. 